\title{
The effect of zinc deficiency on glucose metabolism in meal-fed rats*
}

\author{
BY PHILIP G. REEVES AND BOYD L. O'DELL \\ 322 Chemistry, Department of Biochemistry, University of Missouri, Columbia, Missouri \\ 65211, USA
}

(Received 2 June 1982-Accepted 8 December 1982)

1. The incorporation of uniformly-labelled $\left[{ }^{4} \mathrm{C}\right] \mathrm{glucose}$ into fatty acids and glycogen of adipose tissue and liver was used to assess the effects of zinc deficiency on glucose metabolism in meal-fed rats.

2. Throughout the study, identical feeding regimens were maintained between each of the $\mathrm{Zn}$-deficient groups and their appropriate controls. The feeding regimens were either meal-feeding or ad lib. feeding.

3. $\mathrm{Zn}$ deficiency reduced $\left[{ }^{14} \mathrm{C}\right]$ glucose incorporation into fatty acids of epididymal fat pads of meal-fed rats by $75 \%$ when compared with meal-fed controls.

4. $\mathrm{Zn}$ deficiency caused a slight but significant decrease in [ $\left.{ }^{14} \mathrm{C}\right] \mathrm{glucose}$ incorporation into liver fatty acids of meal-fed fats when compared with meal-fed controls.

5. Zn deficiency significantly increased $\left[{ }^{14} \mathrm{C}\right]$ glucose incorporation into liver glycogen of meal-fed rats in Expt. 2 but not in Expt 1.

6. Some effects of $\mathrm{Zn}$ deficiency on glucose metabolism were shown to be independent of the feeding regimen when a single daily meal was given to both $\mathrm{Zn}$ deficient and control groups. This method of feeding may be a useful approach to study the effects of $\mathrm{Zn}$ on glucose metabolism in the rat.

There is evidence that zinc deficiency in the rat reduces glucose tolerance (Quarterman $\boldsymbol{e t}$ al. 1966; Hendricks \& Mahoney, 1972; Roth et al. 1975). However, Quarterman \& Florence (1972) showed that glucose tolerance is not affected by $\mathrm{Zn}$ deficiency when feeding patterns and food intake are equalized between groups. Quarterman (1969) showed that glucose uptake and utilization are impaired in adipose tissue of $\mathrm{Zn}$-deficient rats when compared with pair-fed controls. These results are open to question since pair-fed control rats tend to become meal-eaters and the method of meal-feeding, which is similar to pair-feeding, has been shown to cause an enhancement of glucose utilization in adipose tissue of rats (Leveille, 1967). The present report describes the effects of $\mathrm{Zn}$ deficiency on glucose metabolism in the rat when identical feeding regimens are used for both deficient and control groups. The series of experiments presented in the present paper used the meal-feeding regimen described by Leveille (1967). The incorporation of uniformly-labelled $\left[{ }^{14} \mathrm{C}\right]$ glucose into fatty acids and glycogen of adipose tissue and liver was used to assess the effects of this feeding regimen on glucose metabolism in the $\mathrm{Zn}$-deficient rat.

\section{MATERIALS AND METHODS}

Male Wistar rats from the departmental colony (mean weight $130 \mathrm{~g}$ ) were housed individually in stainless-steel cages and given access to deionized distilled water. The design of the first experiment was as follows: group 1, meal-fed on a low-Zn diet; group 2, meal-fed on an adequate-Zn diet; group 3, ad lib.-fed on a low-Zn diet; group 4, ad lib.-fed on an adequate- $\mathrm{Zn}$ diet. The second experiment consisted of two groups both of which were meal-fed, with and without added dietary $\mathrm{Zn}$. Meal-fed rats were given free access to the diet for $2 \mathrm{~h} / \mathrm{d}$ between 08.00 and 10.00 hours for 3 weeks, while ad lib.-fed rats had free access to the diet at all times. The basal diet described in Table 1 contained less than $1 \mathrm{mg} \mathrm{Zn} / \mathrm{kg}$. Diets with adequate $\mathrm{Zn}$ were prepared by adding $100 \mathrm{mg} \mathrm{Zn}$ as zinc carbonate $/ \mathrm{kg}$ basal diet.

* Contribution of the Missouri Agricultural Experiment Station, Journal Series no. 9115. 
Table 1. Composition of basal diet $(\mathrm{g} / \mathrm{kg})$

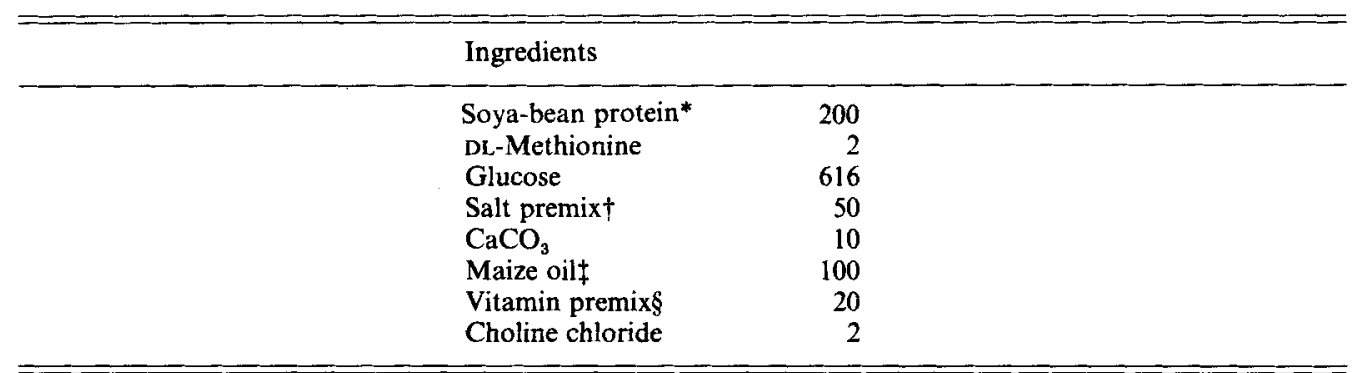

* Promine-R obtained from Central Soya, Chicago, Illinois and extracted with EDTA to remove zinc (O'Dell et al. 1972).

† Salt premix $\left(50 \mathrm{~g} / \mathrm{kg}\right.$ diet) supplied the following concentrations of minerals (g/kg diet): $\mathrm{CaHPO}_{4} 25$, potassium citrate. $\mathrm{H}_{2} \mathrm{O} 7 \cdot 4, \mathrm{~K}_{2} \mathrm{SO}_{4} 2 \cdot 6, \mathrm{NaCl} 3 \cdot 7, \mathrm{MgO} 1 \cdot 2$, ferric citrate $0 \cdot 3, \mathrm{MnCO}_{3} 0 \cdot 18, \mathrm{CrK}\left(\mathrm{SO}_{4}\right)_{2} .12 \mathrm{H}_{2} \mathrm{O}$ $0.019, \mathrm{CuCO}_{3} 0.015, \mathrm{KIO}_{3} 0.5$ (mg/kg diet), $\mathrm{Na}_{2} \mathrm{Se}_{2} \mathrm{O}_{3} .5 \mathrm{H}_{2} \mathrm{O} 0.34$ (mg/kg diet).

$\ddagger$ Mazola $^{13}$ oil; Best Foods Inc., Englewood Cliffs, New Jersey.

$\S$ Vitamin premix in glucose at $20 \mathrm{~g} / \mathrm{kg}$ diet supplied the following concentration ( $\mathrm{mg} / \mathrm{kg}$ diet): thiamin hydrochloride 8.0 , riboflavin 8.0 , pyridoxine hydrochloride 7.0 , niacin 16 , calcium pantothenate 20 , biotin 0.2 , folic acid $2 \cdot 0$, cyanocobalamin $0 \cdot 05$, retinyl acetate $1 \cdot 72$, cholecalciferol $0 \cdot 025, \alpha$-tocopherol $45 \cdot 4$, menadione $1 \cdot 0$.

In both experiments, all rats were fasted for $22 \mathrm{~h}$ between 10.00 and 08.00 hours, after which each was given intragastrically a $20 \mathrm{mmol}$ dose of glucose containing $20 \mu \mathrm{Ci}$ $\left[\mathrm{U}-{ }^{14} \mathrm{C}\right] \mathrm{glucose} / \mathrm{kg}$ body-weight (Palmquist et al. 1977). Rats in Expt 1 were decapitated $3 \mathrm{~h}$ after dosing while rats in Expt 2 were killed at intervals between 0 and $3 \mathrm{~h}$ to study the time-course of glucose-carbon incorporation into fatty acids and glycogen. Both epididymal fat pads and one lobe of liver from each rat were frozen immediately on dry ice and kept at $-20^{\circ}$ until analysed. Blood was collected from the trunk and serum was harvested and frozen.

Adipose tissue and liver were homogenized in water $(1: 1, \mathrm{w} / \mathrm{v})$ in a ground-glass homogenizer. Appropriate portions of the homogenate were saponified in $2 \mathrm{M}$-potassium hydroxide in ethanol $(500 \mathrm{ml} / \mathrm{l})$ in sealed tubes at $100^{\circ}$ for $4 \mathrm{~h}$. Non-saponifiable lipids were removed by three successive extractions with 1 vol. light petroleum (b.p. 30-60'). Samples were acidified to $\mathrm{pH} 2$ by drop-wise addition of sulphuric acid $(600 \mathrm{ml} / 1)$ and the free fatty acids removed by extracting three times with light petroleum. Light-petroleum fractions were combined, washed with $0.3 \mathrm{vol}$. water, transferred to tared test-tubes and evaporated to dryness with a stream of air. Samples were dried in vacuo at $50^{\circ}$ for $4 \mathrm{~h}$ and weighed to the nearest $\mathrm{mg}$. The residue was dissolved in a toluene-based scintillation fluid containing ethanol $(100 \mathrm{ml} / \mathrm{l})$ and assayed for ${ }^{14} \mathrm{C}$.

Glycogen was isolated from liver by the method of Van Handel (1965). ${ }^{14} \mathrm{C}$ incorporated into glycogen was determined by dissolving portions of isolated glycogen in $3 \mathrm{a} 70 \mathrm{~b}$ scintillation cocktail (Research Products, Inc. Morton Grove, Illinois) and counting. Glucose in serum was determined by the glucose oxidase (EC 1.1.3.4) method (Sigma Chemical Co., St Louis, Missouri), and free fatty acids in serum were determined by the method of Laurell \& Tibbling (1967).

The results of the glucose metabolism studies were expressed in $\mu \mathrm{mol}\left[\mathrm{U}-{ }^{-14} \mathrm{C}\right]$ glucose incorporated into fatty acids or glycogen per $\mathrm{g}$ wet tissue weight and per $\mathrm{g}$ product or both. Disintegrations per min values were converted to molar equivalents of glucose based on the specific activity of glucose administered (O'Dea \& Puls, 1979). It was assumed that the entire molecule of $\left[\mathrm{U}^{14} \mathrm{C}\right] \mathrm{glucose}$ would be incorporated into glycogen but only two-thirds of it into fatty acids. 
Table 2. Expt 1. The effect of zinc deficiency and meal-feeding on growth rate and feed consumption in the rat

(Mean values with their standard errors for five observations per group)

\begin{tabular}{|c|c|c|c|c|c|c|}
\hline \multirow[b]{2}{*}{ Treatment } & \multicolumn{2}{|c|}{$\begin{array}{l}\text { Rate of gain } \\
(21 \mathrm{~d})^{*}(\mathrm{~g} / \mathrm{d})\end{array}$} & \multicolumn{2}{|c|}{$\begin{array}{c}\text { Feed intake } \\
(6 \mathrm{~d}) \dagger(\mathrm{g} / \mathrm{d} \text { per } \mathrm{kg} \text { body-wt })\end{array}$} & \multicolumn{2}{|c|}{$\begin{array}{l}\text { Rate of gain } \\
(6 \mathrm{~d}) \ddagger(\mathrm{g} / \mathrm{d})\end{array}$} \\
\hline & Mean & $\mathbf{S E}$ & Mean & $\mathrm{SE}$ & Mean & $\mathrm{SE}$ \\
\hline $\begin{array}{c}\text { Meal-fed } \\
\quad-\mathrm{Zn} \\
+\mathrm{Zn}\end{array}$ & $\begin{array}{r}-0.1 \\
1.8\end{array}$ & $\begin{array}{l}0.1^{a} \\
0.6^{b}\end{array}$ & $\begin{array}{l}49 \\
51\end{array}$ & $\begin{array}{l}5^{a} \\
4^{a}\end{array}$ & $\begin{array}{r}-1.2 \\
1.8\end{array}$ & $\begin{array}{l}0.2^{a} \\
0.6^{b}\end{array}$ \\
\hline $\begin{array}{l}\text { Ad-lib.-fed } \\
\quad-\mathrm{Zn} \\
+\mathrm{Zn}\end{array}$ & $\begin{array}{l}0.7 \\
5.5\end{array}$ & $\begin{array}{l}0 \cdot 1^{c} \\
0 \cdot 2^{d}\end{array}$ & $\begin{array}{l}51 \\
74\end{array}$ & $\begin{array}{l}5^{a} \\
7^{b}\end{array}$ & $\begin{array}{r}-0 \cdot 1 \\
4 \cdot 0\end{array}$ & $\begin{array}{l}0 \cdot 3^{c} \\
0 \cdot 3^{d}\end{array}$ \\
\hline
\end{tabular}

* Average daily gain in body-weight during the $21 \mathrm{~d}$ feeding period.

$\dagger$ Daily feed consumption determined during the last $6 \mathrm{~d}$ of the $21 \mathrm{~d}$ feeding period.

$\ddagger$ Average daily gain in body-weight during last $6 \mathrm{~d}$ of the $21 \mathrm{~d}$ feeding period.

${ }_{a, b, c, d}$ Different superscript letters between treatment group means indicate significant differences $(P \leqslant 0.05)$.

Statistical analysis of data in Expt 1 was done by the general linear model procedures and the method of least squares was used to determine differences between group means (Goodnight \& Sall, 1979). When variances between groups were not homogeneous the analysis was performed on transformed data $\left(Y_{t}=\log _{10} Y\right)$. Untransformed means with their original standard errors were tabulated. The $t$ distribution was used to make inferences about means in the second experiment. Similar results were found in a duplicate set of experiments but only one set is reported here.

\section{RESULTS \\ Expt 1}

Rats given the diet low in $\mathrm{Zn}$ showed typical growth failure whether they were meal-fed or had access to food continuously (Table 2). Furthermore, rats meal-fed the adequate- $\mathrm{Zn}$ diet did not gain at the maximal rate even though they were adapted to meal-feeding. During the last $6 \mathrm{~d}$ of the trial the $\mathrm{Zn}$-deficient, meal-fed rats ate the same amount of feed on a per $\mathrm{kg}$ body-weight basis as the meal-fed controls but actually lost weight. Rats given the low-Zn diet ad lib. did not gain weight during this period.

The dramatic effects of meal-feeding on the incorporation of labelled glucose into fatty acids of adipose tissue are shown in Fig. 1. Rats meal-fed diets containing adequate $\mathbf{Z n}$ incorporated 120 times more label into fatty acids on a per $\mathrm{g}$ tissue basis than those given the same diet ad lib. On the other hand, Zn-deficient, meal-fed rats incorporated much less ${ }^{14} \mathrm{C}$ into the fatty acids of this tissue. $\mathrm{Zn}$ deficiency had no effect when rats were fed $a d$ lib.

Even though rats meal-fed a diet adequate in $\mathrm{Zn}$ had only 2.5 times more epididymal tissue than meal-fed, $\mathrm{Zn}$-deficient rats, their capacity to incorporate glucose into fatty acids was eight times greater (Table 3). Rats given the Zn-supplemented diet ad lib. had three times more epididymal adipose tissue than the meal-fed group but had significantly less total ${ }^{14} \mathrm{C}$ incorporated into total tissue fatty acids.

Leveille (1967) showed that liver was a major site of adaptation to meal-feeding. Our experiments also demonstrated this phenomenon although when expressed per unit tissue the response was not as large as found in adipose tissue (Fig. 2). Rats meal-fed diets with an adequate level of $\mathrm{Zn}$ incorporated ten times more glucose-C into liver fatty acids on a 


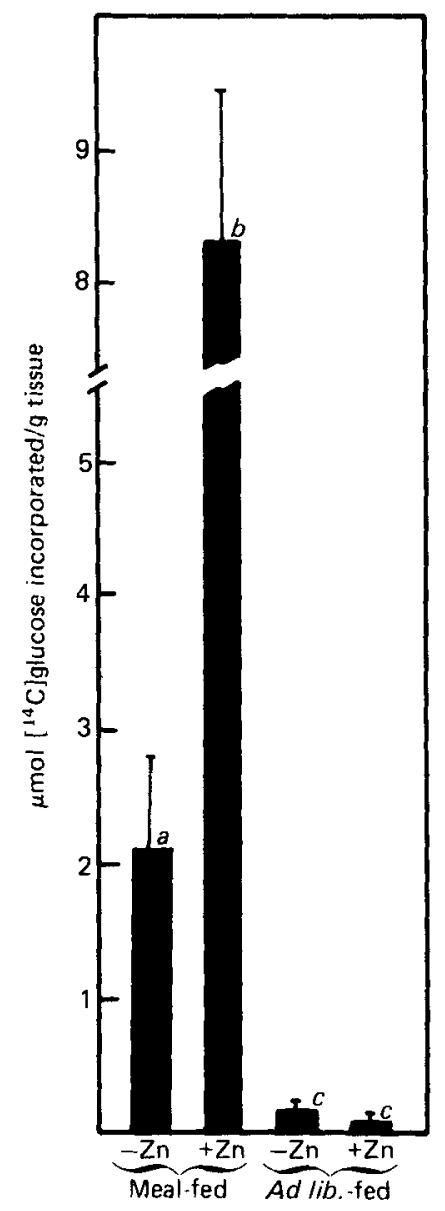

Fig. 1. Incorporation of glucose into fatty acids of epididymal fat pads of zinc-deficient and control rats that were meal-fed or $a d$ lib.-fed for a period of $21 \mathrm{~d}$. After an overnight fast $(22 \mathrm{~h})$ rats were given an intragastric dose of radiolabelled glucose $\left(20 \mathrm{mmol}\right.$ plus $20 \mu \mathrm{Ci}$ [U- ${ }^{14} \mathrm{C}$ lglucose $/ \mathrm{kg}$ body-weight). After $3 \mathrm{~h}$ the amount of ${ }^{14} \mathrm{C}$ incorporated into fatty acids was determined. All values are means of five determinations with their standard errors represented by vertical bars. Different letters $(a, b$ or $c)$ between means indicate a significant difference $(P \leqslant 0.05)$.

per $\mathrm{g}$ liver basis than did ad lib.-fed rats. Compared with adipose tissue the livers of $\mathrm{Zn}$-deficient rats adapted well to meal-feeding; they incorporated $70 \%$ as much glucose into fatty acids as the livers of rats meal-fed a $\mathrm{Zn}$-adequate diet. $A d$ lib. feeding of the $\mathrm{Zn}$-deficient diet caused a two-fold increase in glucose incorporation by the liver compared with ad lib.-fed controls. The fatty acid pool size in the liver of the $\mathrm{Zn}$-deficient, ad lib.-fed rats was half that of the ad lib.-fed controls while the amount of label per $\mathrm{g}$ of fatty acids was five times greater (Table 4). The reason for this large difference is not obvious but an increased rate of turnover of fatty acids by the liver of the $\mathrm{Zn}$-deficient rats is suggested. $\mathrm{Zn}$ deficiency also decreased the concentration of liver fatty acids in meal-fed rats while the amount of ${ }^{14} \mathrm{C}$ incorporated per unit fatty acid remained the same (Table 4).

There was no significant difference in total liver weights between meal-fed $\mathrm{Zn}$-adequate and $\mathrm{Zn}$-deficient rats but the livers of the $\mathrm{Zn}$-adequate group incorporated one and a half times as much of the $\left[{ }^{14} \mathrm{C}\right]$ glucose into total fatty acids as the deficient group (Table 3). In 
Table 3. Expt 1. Effects of zinc deficiency and meal-feeding on tissue weights and on $\left[U-{ }^{14} \mathrm{C}\right]$ glucose incorporation into total fatty acids of epididymal fat pads and liver

(Mean values with their standard errors for five observations per group)

\begin{tabular}{|c|c|c|c|c|c|c|c|c|}
\hline \multirow[b]{3}{*}{ Treatment } & \multicolumn{4}{|c|}{ Tissue wt (g) } & \multicolumn{4}{|c|}{$\begin{array}{l}{\left[{ }^{14} \mathrm{ClGlucose} \text { incorporation into }\right.} \\
\text { fatty acids/organ }(\% \text { of dose })\left(\times 10^{2}\right)\end{array}$} \\
\hline & \multicolumn{2}{|c|}{ Fat tissue } & \multicolumn{2}{|c|}{ Liver } & \multicolumn{2}{|c|}{ Fat tissue } & \multicolumn{2}{|c|}{ Liver } \\
\hline & Mean & $\mathrm{SE}$ & Mean & $\mathbf{S E}$ & Mean & SE & Mean & SE \\
\hline $\begin{array}{l}\text { Meal-fed } \\
\quad-Z n \\
+Z n\end{array}$ & $\begin{array}{l}0.4 \\
1 \cdot 0\end{array}$ & $\begin{array}{l}0 \cdot 1^{a} \\
0 \cdot 3^{a}\end{array}$ & $\begin{array}{l}3 \cdot 6 \\
4 \cdot 8\end{array}$ & $\begin{array}{l}0 \cdot 4^{\alpha} \\
1 \cdot 0^{\alpha}\end{array}$ & $\begin{array}{r}2 \cdot 1 \\
16 \cdot 0\end{array}$ & $\begin{array}{l}0 \cdot 8^{a} \\
1 \cdot 0^{b}\end{array}$ & $\begin{array}{r}8 \cdot 0 \\
11 \cdot 5\end{array}$ & $\begin{array}{l}1 \cdot 6^{a} \\
0 \cdot 5^{b}\end{array}$ \\
\hline $\begin{array}{l}\text { Ad-lib.-fed } \\
\quad-\mathrm{Zn} \\
+\mathrm{Zn}\end{array}$ & $\begin{array}{l}0.5 \\
3 \cdot 0\end{array}$ & $\begin{array}{l}0 \cdot 1^{a} \\
0 \cdot 3^{b}\end{array}$ & $\begin{array}{l}4.0 \\
6 \cdot 3\end{array}$ & $\begin{array}{l}0 \cdot 2^{a} \\
0 \cdot 3^{b}\end{array}$ & $\begin{array}{l}0 \cdot 2 \\
0 \cdot 3\end{array}$ & $\begin{array}{l}0.05^{c} \\
0.07^{c}\end{array}$ & $\begin{array}{l}2 \cdot 6 \\
0 \cdot 9\end{array}$ & $\begin{array}{l}0 \cdot 2^{c} \\
0 \cdot 1^{d}\end{array}$ \\
\hline
\end{tabular}

$a, b, c, d$ Different superscript letters between treatment group means indicate significant differences $(P \leqslant 0.05)$.

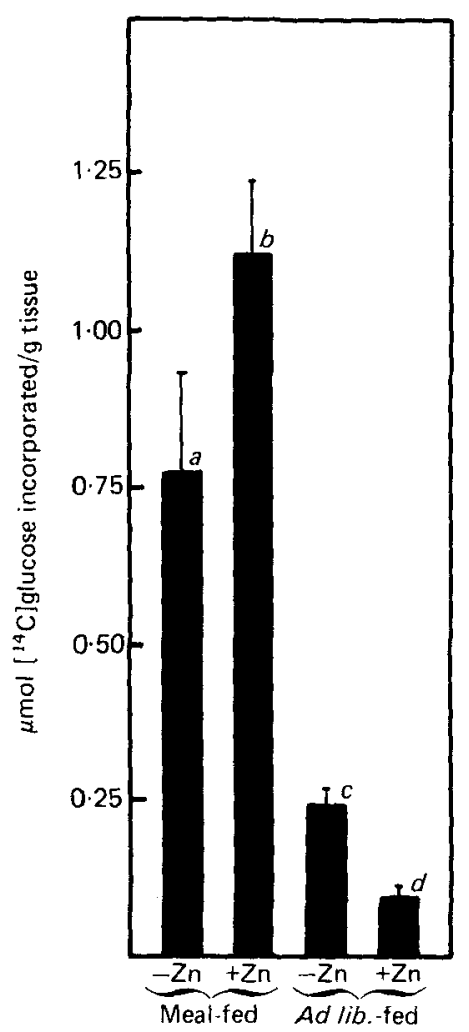

Fig. 2. Incorporation of glucose into fatty acids of liver of zinc-deficient and control rats that were meal-fed or ad lib.-fed for a period of $21 \mathrm{~d}$. After an overnight fast $(22 \mathrm{~h})$ rats were given an intragastric dose of radiolabelled glucose $\left(20 \mathrm{mmol}\right.$ plus $20 \mu \mathrm{Ci}\left[\mathrm{U}-{ }^{14} \mathrm{C}\right.$ ]glucose $/ \mathrm{kg}$ body-weight). After $3 \mathrm{~h}$ the amount of ${ }^{14} \mathrm{C}$ incorporated into fatty acids was determined. All values are means of five determinations with their standard errors represented by vertical bars. Different letters $(a, b, c$ or $d)$ between means indicate a significant difference $(P \leqslant 0.05)$. 


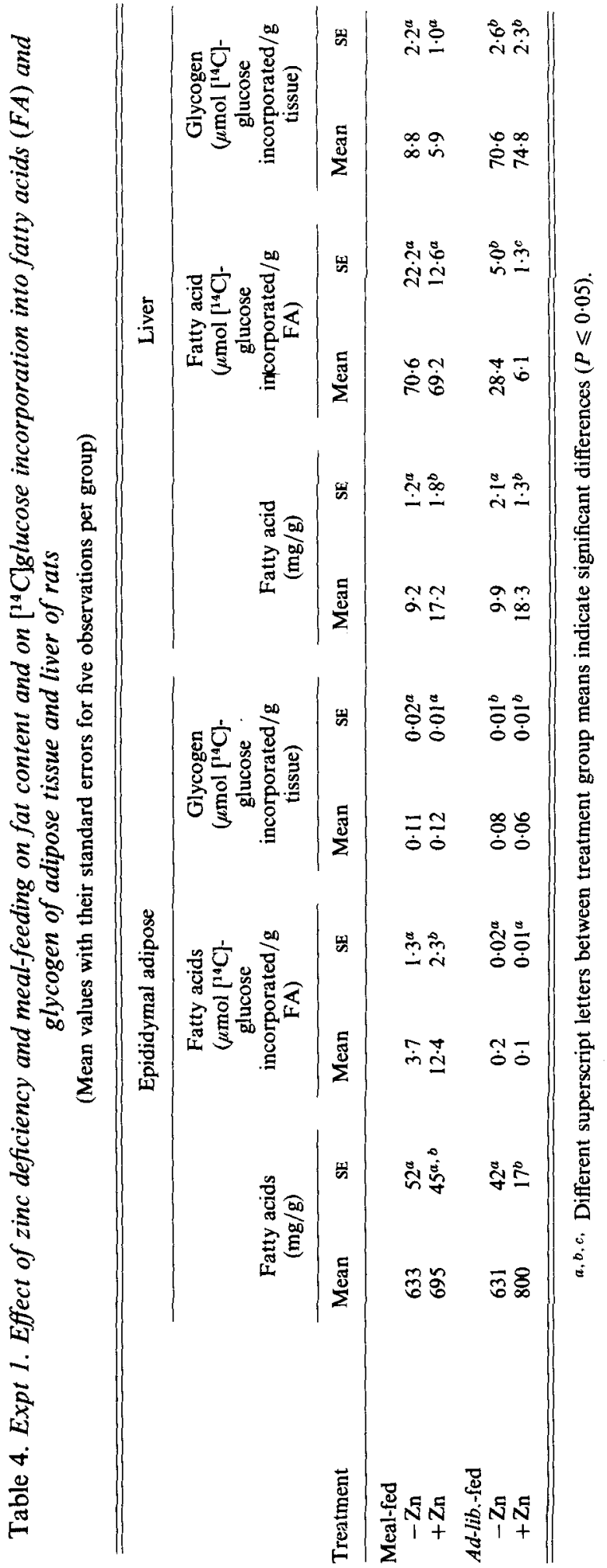


Table 5. Expt 1. Effect of zinc deficiency and meal-feeding on serum levels of Zn, glucose and free fatty acids in rats

(Mean values with their standard errors for five observations per group)

\begin{tabular}{|c|c|c|c|c|c|c|}
\hline \multirow[b]{2}{*}{ Treatment } & \multicolumn{2}{|c|}{$\underset{(\mu \mathrm{mol} / \mathrm{l})}{\text { Zinc }}$} & \multicolumn{2}{|c|}{$\begin{array}{c}\text { Glucose } \\
(\mathrm{mmol} / \mathrm{l})\end{array}$} & \multicolumn{2}{|c|}{$\begin{array}{l}\text { Free fatty acids } \\
(\mu \mathrm{mol} / 1)\end{array}$} \\
\hline & Mean & $\mathbf{S E}$ & Mean & $\mathbf{S E}$ & Mean & $\mathrm{SE}$ \\
\hline $\begin{array}{c}\text { Meal-fed } \\
-\mathrm{Zn} \\
+\mathrm{Zn}\end{array}$ & $\begin{array}{r}8 \cdot 0 \\
14 \cdot 5\end{array}$ & $\begin{array}{l}0.4^{a} \\
1 \cdot 4^{b}\end{array}$ & $\begin{array}{l}0.65 \\
0.56\end{array}$ & $\begin{array}{l}0.02^{a} \\
0.03^{b}\end{array}$ & $\begin{array}{l}809 \\
849\end{array}$ & $\begin{array}{l}51 \\
94\end{array}$ \\
\hline $\begin{array}{l}\text { Ad-lib,-fed } \\
\quad-\mathrm{Zn} \\
+\mathrm{Zn}\end{array}$ & $\begin{array}{r}9 \cdot 8 \\
13 \cdot 8\end{array}$ & $\begin{array}{l}0 \cdot 4^{a} \\
0.9^{b}\end{array}$ & $\begin{array}{l}0.60 \\
0.62\end{array}$ & $\begin{array}{l}0.03^{a, b} \\
0.02^{a, b}\end{array}$ & $\begin{array}{l}773 \\
762\end{array}$ & $\begin{array}{l}44 \\
53\end{array}$ \\
\hline
\end{tabular}

${ }^{a, b}$ Different superscript letters between treatment group means indicate significant differences $(P \leqslant 0.05)$.

contrast, Zn-deficient, ad lib.-fed rats had significantly smaller livers than the group receiving adequate $\mathrm{Zn}$ but incorporated a significantly higher amount of the $\left[{ }^{14} \mathrm{C}\right] \mathrm{glucose}$. This also could be accounted for if the rate of turnover of fatty acids in liver of $\mathrm{Zn}$-deficient rats were higher.

The effects of $\mathrm{Zn}$ deficiency and meal-feeding on glucose incorporation into glycogen of liver and adipose tissue were less definitive than the effects on its incorporation into fatty acids, but the results are noteworthy (Table 4). Meal-feeding the adequate- $\mathrm{Zn}$ diet increased glucose incorporation into glycogen of adipose tissue, but decreased its incorporation into liver glycogen by a factor of approximately thirteen. In this experiment, $\mathrm{Zn}$-deficiency caused an insignificantly higher incorporation of glucose into liver glycogen of meal-fed rats. There was a significant effect of $\mathrm{Zn}$-deficiency in Expt 2 of the present report. $\mathrm{Zn}$ deficiency had no effect on liver glycogen in ad lib.-fed rats.

Serum glucose was determined $3 \mathrm{~h}$ after administration of glucose and the only significant difference was a slightly higher level in the $\mathrm{Zn}$-deficient, meal-fed group (Table 5). Free fatty acid levels in serum were not affected by either meal-feeding or $\mathrm{Zn}$ status. These results are at variance with those reported by Quarterman \& Florence (1972) who found a two-fold increase in plasma free fatty acids in ad lib.-fed, $\mathrm{Zn}$-deficient rats when compared with pair-fed controls, which would tend to be meal-eaters. Their rats had been fasted, while in the present experiment rats were fasted overnight and refed glucose before fatty acid analysis was done.

\section{Expt 2}

The results of this experiment, designed to determine the effects of $\mathrm{Zn}$ deficiency on the time-course of glucose metabolism of meal-fed rats, are shown in Fig. 3. At $60 \mathrm{~min}$ the accumulation of ${ }^{14} \mathrm{C}$-labelled glucose in fatty acids of epididymal fat pads of $\mathrm{Zn}$-deficient, meal-fed rats was greatly decreased compared with controls (Fig. 3A). The amount of total fatty acids was not different between the treated and control groups. This resulted in a decreased incorporation of $\left[{ }^{14} \mathrm{C}\right]$ glucose per $\mathrm{g}$ fatty acid (values not shown). This finding indicates that either glucose was not entering the fat cells or that it was quickly metabolized after entry. Studies in the authors' laboratory with isolated fat cells from $\mathrm{Zn}$-deficient rats showed that ${ }^{14} \mathrm{CO}_{2}$ production was reduced in proportion to ${ }^{14} \mathrm{C}$-labelled fatty acid synthesized, suggesting that glucose did not enter the cell to an appreciable extent (P. G. Reeves \& B. L. O'Dell, unpublished results). 


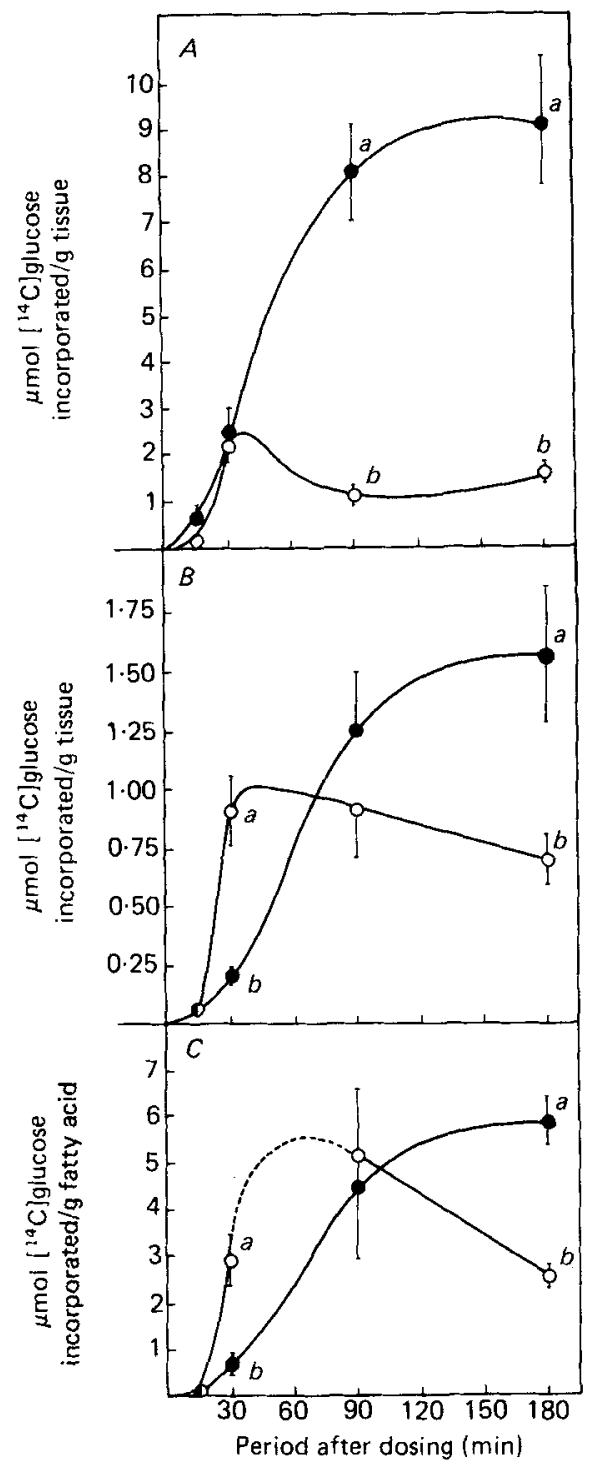

Fig. 3. Incorporation of glucose into fatty acids of epididymal fat pads (A) and liver (B) of meal-fed zinc-deficient $(O)$ and control $(O)$ rats with respect to time. After $21 \mathrm{~d}$ of meal-feeding the rats were fasted overnight $(22 \mathrm{~h})$ and given an intragastric dose of radiolabelled glucose $(20 \mathrm{mmol}$ plus $20 \mu \mathrm{Ci}$ $\left[\mathrm{U}^{14} \mathrm{C}\right]$ glucose $/ \mathrm{kg}$ body-weight). The amounts of ${ }^{14} \mathrm{C}$ incorporated into epididymal fat pads and liver fatty acids were determined at the time intervals indicated. (C) The incorporation of ${ }^{14} \mathrm{C}$-labelled glucose into liver. (-...--), An estimation of the line between the two points. Each point is the mean of five determinations with standard errors represented by vertical bars. Different superscript letters $(a$ and $b)$ between means at each time period indicate a significant difference $(P \leqslant 0 \cdot 05)$.

The livers of the $\mathrm{Zn}$-deficient, meal-fed rats, on the other hand, rapidly accumulated ${ }^{14} \mathrm{C}$-labelled fatty acids (Fig. 3 B). At $30 \mathrm{~min}$ the level was six times greater than that in the controls but by $90 \mathrm{~min}$ the level had begun to drop. This trend continued through $180 \mathrm{~min}$ resulting in a significantly lower incorporation at this time by the $\mathrm{Zn}$-deficient group. The 


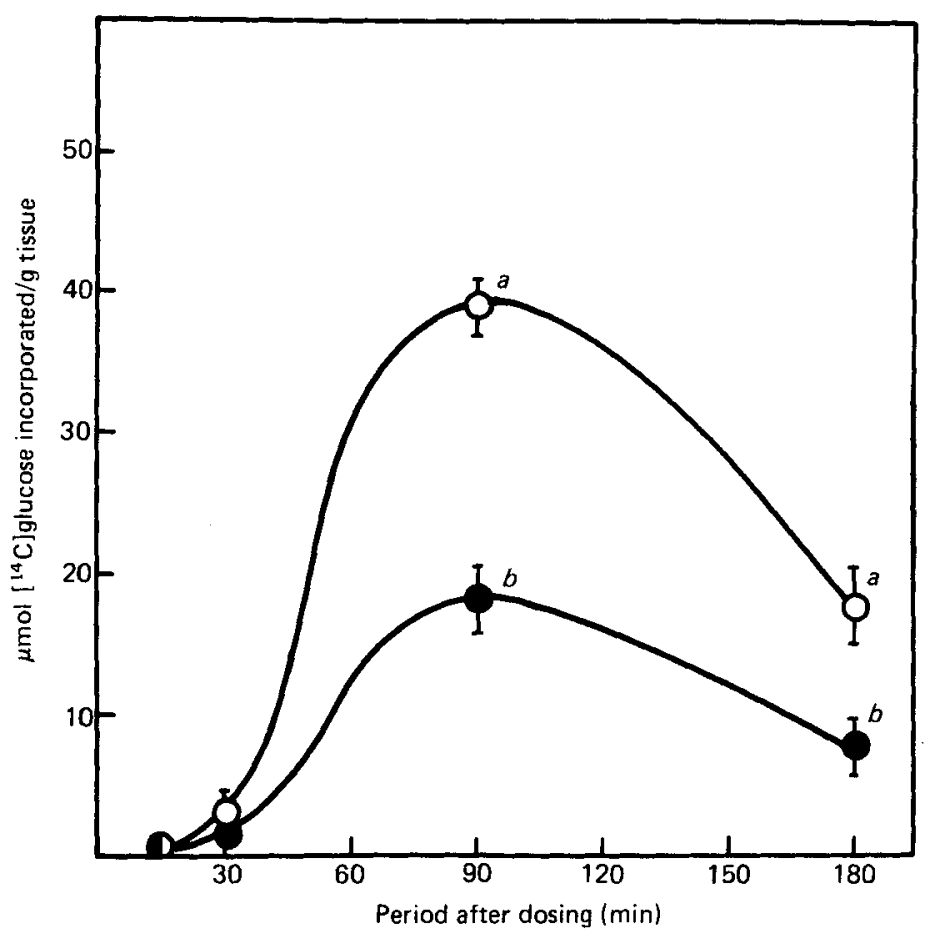

Fig. 4. Incorporation of glucose into liver glycogen of meal-fed zinc-deficient $(O)$ and control $(O)$ rats with respect to time. After $21 \mathrm{~d}$ of meal-feeding the rats were fasted overnight $(22 \mathrm{~h})$ and given an intragastric dose of radiolabelled glucose $(20 \mathrm{mmol}$ plus $20 \mu \mathrm{Ci}$ [U-14 C]glucose $/ \mathrm{kg}$ body-weight). At the time intervals indicated rats were decapitated and the amount of ${ }^{14} \mathrm{C}$ incorporated into liver glycogen was determined. Each point is the mean of five determinations with standard errors represented by vertical bars. Different superscript letters $(a$ and $b$ ) between means at each time period indicate a significant difference $(P \leqslant 0.05)$.

fatty acid level did not change in either group over this period but the amount expressed as ${ }^{14} \mathrm{C}$-labelled glucose incorporated per $\mathrm{g}$ fatty acid followed the same time-course as the amount expressed per $\mathrm{g}$ liver (Fig. 3C). This finding suggests that the turnover rate of fatty acids was significantly increased in this tissue.

Glycogen metabolism in liver was also affected by $\mathrm{Zn}$ deficiency. $\mathrm{Zn}$-deficient, meal-fed rats accumulated twice as much ${ }^{14} \mathrm{C}$-labelled glucose into glycogen in liver as the meal-fed controls (Fig. 4). These results and those representing fatty acid incorporation suggest that glucose entry into the liver cells of $\mathrm{Zn}$-deficient rats was not as impaired as it appeared to be in fat cells.

The effect of $\mathrm{Zn}$ deficiency on glucose absorption was determined by excising the entire intestinal tract at $90 \mathrm{~min}$ and measuring the glucose content in the gut lumen. The amount of glucose remaining at this time showed that $\mathrm{Zn}$-adequate rats absorbed $13 \%$ more glucose than the $\mathrm{Zn}$-deficient ones (Table 6). It is unlikely that this would be enough to account for the large differences in label incorporation into fat tissue. There was no effect of $\mathrm{Zn}$ deficiency on the level of serum glucose at any time (values not shown).

$\mathrm{Zn}$ deficiency did not affect the amount of glucose absorbed per $\mathrm{g}$ intestine but decreased the rate of absorption based on body-weight. This suggests that the absorptive area in the intestine of $\mathrm{Zn}$-deficient rats was less than that of controls (Table 6). 
Table 6. Expt 2. The effect of zinc deficiency on glucose absorption in meal-fed rats

(Mean values with their standard errors for five observations per group. Rats were given $20 \mathrm{mmol}$ glucose/ $\mathrm{kg}$ body-wt by stomach tube. After $90 \mathrm{~min}$ the amount of glucose remaining in the gastrointestinal lumen was determined)

\begin{tabular}{|c|c|c|c|c|}
\hline \multirow[b]{3}{*}{ Treatment } & \multicolumn{4}{|c|}{ Glucose absorbed } \\
\hline & \multicolumn{2}{|c|}{$\mathrm{g} / \mathrm{kg}$ body-wt per $\mathrm{h}$} & \multicolumn{2}{|c|}{$\mathrm{mg} / \mathrm{g}$ intestine per $\mathrm{h}$} \\
\hline & Mean & SE & Mean & $\mathbf{S E}$ \\
\hline$-\mathrm{Zn}$ & $2 \cdot 3$ & $0.06^{a}$ & 107 & $8^{a}$ \\
\hline$+\mathrm{Zn}$ & $2 \cdot 0$ & $0 \cdot 10^{b}$ & 96 & $5^{a}$ \\
\hline
\end{tabular}

$a, b$ Different superscript letters between treatment group means indicate significant differences $(P \leqslant 0 \cdot 05)$.

\section{DISCUSSION}

The present study clearly showed that metabolic adaptation to meal-feeding in the rat was markedly affected by $\mathrm{Zn}$ deficiency. The response of the meal-fed control rat was manifested by a greater than 120-fold increase in the incorporation of an intragastric dose of $\left[{ }^{14} \mathrm{C}\right]$ glucose into adipose tissue fatty acids while the $\mathrm{Zn}$-deficient rats responded with only a fourteen-fold increase when compared with ad lib.-fed controls. The differences between these groups with respect to ${ }^{14} \mathrm{C}$ incorporation into liver fatty acids was much less dramatic. In addition, the $\mathrm{Zn}$-deficient, meal-fed rats had an increased capacity to incorporate glucose into glycogen in liver when compared with the meal-fed controls.

The different effects of $\mathrm{Zn}$ deficiency on glucose metabolism in liver and fat cells may be related to the difference in the effect of insulin on glucose uptake and metabolism in these tissues. Fat cells require insulin for the uptake of glucose; therefore, if this process were hindered by $\mathrm{Zn}$ deficiency the tissue would not adapt to meal-feeding and the incorporation of glucose into fatty acids would be decreased. Liver cells, on the other hand, do not require insulin for glucose uptake (Renold et al. 1955; Cahill et al. 1958), nor is insulin required by the liver cells for stimulation of glycogen synthase (EC 2.4.1.11) activity by glucose (Mulmed et al. 1979). Therefore, the uptake of glucose into liver tissue would not be affected by the deficiency and the adaptation response most likely would remain intact.

The detrimental effect of $\mathrm{Zn}$ deficiency on the uptake and subsequent utilization of glucose by adipose tissue could be brought about in two ways. First, there could be a direct effect on binding of insulin to the plasma membrane; second, there could be an indirect effect of reduced circulating levels of insulin caused by inhibition of its release from the pancreas. The latter is in doubt because of the questionable effect that $\mathrm{Zn}$ deficiency has on insulin secretion. Some reports suggest that the deficiency reduces insulin secretion (Huber \& Gershoff, 1973; Roth \& Kirchgessner, 1979) and others found no effect (Roth \& Kirchgessner, 1975; Brown et al. 1975). These conflicting results could be due to the effects that different feeding regimens have on insulin secretion. It has been shown that the pancreas of the fasted rat secretes less insulin than that of the fed rat (Mulmed et al. 1979) and that secretion in meal-fed rats is greater than in ad lib.-fed rats when stimulated by glucose (Wiley \& Leveille, 1970). It appears, therefore, that the level of plasma insulin in the $\mathrm{Zn}$-deficient rat may depend greatly on the eating regimen at the time of the test. Roth \& Kirchgessner (1979) carefully controlled feed intake, time of fasting and frequency of feeding and attempted to show that $\mathrm{Zn}$-deficient rats had lower insulin secretion than 
controls. However, the results were inconsistent and the large variations within groups made it difficult to draw definite conclusions. Brown et al. (1975) showed that the plasma insulin levels of rats given a $\mathrm{Zn}$-deficient diet for as long as $50 \mathrm{~d}$ were the same as those in pair-weighed controls. It is our conclusion that insulin synthesis and secretion do not adequately explain the effects of $\mathrm{Zn}$ deficiency on glucose metabolism in the rat.

Studies have shown that the effect of $\mathrm{Zn}$ deficiency on glucose metabolism in adipose tissue is consistent with the hypothesis that the effect occurs at the cellular level. It has been shown that slices of fat pads from $\mathrm{Zn}$-deficient rats incorporate less glucose- $\mathrm{C}$ into fatty acids and $\mathrm{CO}_{2}$ than those from pair-fed or meal-fed controls respectively (Quarterman, 1969; P. G. Reeves \& B. L. O'Dell, unpublished results). This occurred even in the presence of excess insulin. Quarterman (1969) also found that the addition of $\mathrm{Zn}$ to fat pad preparations from $\mathrm{Zn}$-deficient rats restored glucose uptake. We have been unable to show a restorative effect with physiological levels of $\mathrm{Zn}$.

Even though glucose uptake into liver may not be affected by $\mathrm{Zn}$ through its possible effect on insulin activity, the conversion of glucose to fatty acids and glycogen in liver is altered by $\mathrm{Zn}$ deficiency. A time study showed that the peak of incorporation of an intragastric dose of glucose into fatty acids occurred between 30 and $60 \mathrm{~min}$ but had declined significantly by $180 \mathrm{~min}$. When a similar dose was given to $\mathrm{Zn}$-adequate, meal-fed rats the peak of incorporation occurred at or after $180 \mathrm{~min}$. It appears that the deficiency caused a more rapid turnover of fatty acids, in this tissue. At the same time, glycogen synthesis in the $\mathrm{Zn}$-deficient rat was increased significantly above the controls. This increase probably was not the result of lower levels of liver glycogen in the $\mathrm{Zn}$-deficient rats before glucose intubation. It was shown recently that fasted-refed $\mathrm{Zn}$-deficient rats adapt by increasing their capacity to synthesize glycogen two-fold over similar, fed controls, even though the initial level of liver glycogen was not significantly different between groups (P. G. Reeves \& B. L. O'Dell, unpublished results). The biochemical basis of increased glycogen synthesis in $\mathrm{Zn}$ deficiency is unknown but may be the result of increased glycogen synthase activity.

The metabolism of glucose in $\mathrm{Zn}$-deficient rats has been difficult to study because $\mathrm{Zn}$ deficiency reduces feed intake. It is well-known that alterations in feed intake alone can cause dramatic effects on glucose metabolism. The present study has shown some effects of $\mathrm{Zn}$ deficiency on glucose metabolism that may be independent of a feeding effect. The incorporation of the single daily meal into the feeding regimen of both the treated and control groups appears to be a useful approach to the study of glucose metabolism in the $\mathrm{Zn}$-deficient rat.

The authors wish to thank Linda Winfrey and Melanie Conway for their expert assistance in preparing the manuscript. Part of the support for this research was provided by the US Public Health Service, grant no. HL11614.

\section{REFERENCES}

Brown, E. D., Penhos, J. C., Recant, L. \& Smith, J. C. Jr. (1975). Proc. Soc. expl. Biol. Med. $150,557$.

Cahill, G. F. Jr, Ashmore, J., Earle, A. S. \& Zottur, S. (1958). Am. J. Physiol. 192, 491.

Goodnight, J. H. \& Sall, J. P. (1979). In Statistical Analysis User's Guide, p. 121 [J. T. Helwig and D. A. Council, editors]. Cary, NC: SAS Institute Inc.

Hendricks, D. G. \& Mahoney, A. W. (1972). J. Nutr. 102, 1079.

Huber, A. M. \& Gershoff, S. N. (1973). J. Nutr. 103, 1739.

Laurell, S. \& Tibbling, G. (1967). Clinica. chim, Acta 16, 57.

Leveille, G. A. (1967). Proc. Soc. expl. Biol. Med. 125, 85.

Mulmed, L. N., Gannon, M. C., Gilboe, D. P., Tan, A. W. H. \& Nuttall, F. Q. (1979). Diabetes $28,231$.

O’Dea, K. \& Puls, W. (1979). Metabolism 28, 308.

O'Dell, B. L., Burpo, C. E. \& Savage, J. E. (1972). J. Nutr. 102, 653. 
Palmquist, D. L., Learn, D. B. \& Baker, N. (1977). J. Nutr. 107, 502.

Quarterman, J. (1969). Biochim. biophys. Acta 177, 644.

Quarterman, J. \& Florence, E. (1972). Br. J. Nutr. 28, 75.

Quarterman, J., Mills, C. F. \& Humphries, W. R. (1966). Biochem. Biophys. Res. Commun. $25,354$.

Renold, A. E., Hastings, A. B., Nesbett, F. B. \& Ashmore, J. (1955). J. biol. Chem. 213, 135.

Roth, H.-P. \& Kirchgessner, M. (1975). Int. Z. Vit. Ern. Forsch. 45, 201.

Roth, H.-P. \& Kirchgessner, M. (1979). Z. Tierphysiol. Tierernahrung. Futtermittelkde 42, 287.

Roth, H.-P., Schneider, U. \& Kirchgessner, M. (1975) Archs. Tierernahrung. 25, 545.

Van Handel, E. (1965). Analyt. Biochem. 11, 256.

Wiley, J. N. \& Leveille, G. A. (1970). J. Nutr. 100, 1073. 